\title{
Colgajo miomucoso de buccinador en la reconstrucción de defectos del área maxilofacial
}

\author{
The buccinator myomucosal flap for the reconstruction \\ of defects in the maxillofacial area
}

\author{
R. González García1, L. Naval Gías², F.J. Rodríguez Campo², V. Escorial Hernández', P.L. Martos', \\ J. Sastre Pérez², M.F. Muñoz Guerra², J.L. Gil-Díez Usandizaga3, F.J. Díaz González ${ }^{4}$
}

Resumen: El colgajo miomucoso de buccinador (CMB) constituye una alternativa válida para la reconstrucción de defectos intraorales de tamaño moderado. Se caracteriza por su buena plegabilidad, excelente color y textura, además de una mínima morbilidad de la zona donante.

En el presente trabajo se describen las particularidades anatómicas de dicho colgajo, así como las diferentes técnicas quirúrgicas que pueden emplearse para su obtención. Su utilización en diferentes defectos de la cavidad oral, ilustra la versatilidad del mismo. Presentamos 4 casos de reconstrucción de defectos del área maxilofacial: dos pacientes con carcinoma epidermoide de suelo de boca, un paciente con melanoma de mucosa y un paciente con fisura palatina. Se obtuvieron resultados óptimos en cuanto a cobertura del defecto postquirúrgico, estética y función. En todos los casos la morbilidad de la zona donante fue mínima. Dadas sus particularidades anatómicas, debe realizarse una cuidadosa técnica de obtención del mismo. La proximidad del CMB a la gran mayoría de los defectos de la cavidad oral y su aceptable espesor, hace del mismo una opción reconstructiva eficaz, sobre todo en aquellos pacientes en los que el tamaño del defecto y/o la existencia de patología asociada desaconsejan el uso de otros colgajos.

Palabras clave: Colgajo miomucoso de buccinador; Reconstrucción; Defectos orales y maxilofaciales.

Recibido: 20 de noviembre de 2004

Aceptado: 25 de mayo de 2005

\footnotetext{
1 Médico residente

2 Médico adjunto

3 Jefe de Sección

4 Jefe de Servicio

Servicio de Cirugía Oral y Maxilofacial

Hospital Universitario de La Princesa. Madrid, España.
}

Abstract: The buccinator myomucosal flap (BMF) constitutes a valid alternative for the reconstruction of moderate defects of the oral cavity. It is characterized by a good pliability, excellent color and texture and minimum donor site morbidity. In this report, the anatomical particularities and the different surgical techniques for BMF are described. Its use in patients with different defects of the oral cavity illustrates its versatility. We present 4 cases of reconstruction of defects of the maxillofacial area: two cases consisting in squamous cell carcinoma of the floor of the mouth, another patient with melanoma of the oral mucosa and one patient with a palatine fissure. All of them underwent primary reconstruction by means of BMF. Good results were obtained in relation to covering of the defect, aesthetics and function. Morbidity was minimal in the donor site. Due to its anatomical features, an adequate surgical technique must be performed. Proximity of the BMF to the vast majority of defects of the oral cavity, and its acceptable thickness, show the flap to be a reliable reconstructive procedure. This is especially valid in those patients where the size of the defect and the existence of comorbidity advise against the use of other flaps.

Key words: Buccinator myomucosal flap; Reconstruction; Oral maxillofacial defects. 


\section{Introducción}

La reconstrucción de defectos pequeños del área maxilofacial se realiza normalmente con colgajos locales. Los grandes defectos se reconstruyen con colgajos regionales vascularizados o con colgajos libres microvascularizados. En defectos de tamaño moderado existe controversia acerca del método reconstructivo a emplear. En numerosas ocasiones dichos defectos no son susceptibles de reconstrucción con colgajos locales debido a limitaciones del tipo de longitud del pedículo, características pláticas del material donante y variabilidad anatómica vascular. Sin embargo, el empleo de colgajos libres microvascularizados o de colgajos regionales vascularizados puede no estar indicado, por presentar un volumen excesivo, morbilidad alta de la zona donante, presencia de comorbilidad o riesgo quirúrgico alto, e incremento excesivo del tiempo operatorio. En estos casos, se pueden emplear colgajos pediculados como el de músculo temporal, fascia temporoparietal, músculo frontal, nasolabial, paladar, platisma y esternocleidomastoideo. Otra alternativa, recientemente popularizada, es el colgajo miomucoso de buccinador (CMB).

En 1975, Kaplan, ${ }^{1}$ utilizó un colgajo de mucosa bucal para la reconstrucción del paladar blando. Para mejorar la vascularización de la mucosa, en 1987, Maeda y cols. ${ }^{2}$ realizaron el colgajo de Kaplan junto con fibras del músculo buccinador (MB), a lo largo de toda su longitud, para la reparación de paladar hendido. Ese mismo año, Rayner y Arscott, $^{3}$ describieron el colgajo miomucoso bucal pediculado al ángulo de la boca para la reconstrucción del labio. Bozzola y cols. ${ }^{4}$ en 1989, describieron la arteria bucal (AB) como el principal pedículo para el MB. En 1991, Carstens y cols. ${ }^{5}$ describieron el colgajo miomucoso en isla de $M B$ pediculado a la arteria y vena facial ( $A F, V F)$. Refirieron que el principal aporte sanguíneo del MB no llegaba por la AB sino por la AF. Ono y cols. ${ }^{6}$ en 1997, utilizaron el colgajo miomucoso bucal unilateral para la reconstrucción de defectos totales del bermellón del labio inferior.

En el presente trabajo describimos con detalle la reconstrucción de diferentes defectos de la cavidad oral por medio del CMB. Asimismo, se realiza una revisión de la literatura y nuestra experiencia en 4 casos con defectos de la cavidad oral.

\section{Anatomía}

El MB recibe su aporte arterial de 3 fuentes principales. Estas son: la $A B$ (rama de la arteria maxilar interna), la AF (rama de la arteria carótida externa) y la arteria alveolar posterosuperior (AAPS) (rama de la arteria maxilar interna). Tradicionalmente se consideró la $A B$ como el principal aporte sanguíneo del músculo buccinador. Los estudios más recientes refieren la AF como la principal responsable de la irrigación del músculo. ${ }^{5}$ La $A B$ avanza hacia abajo y adelante bajo el músculo pterigoideo lateral para alcanzar la mitad posterior del músculo buccinador. La AF da una rama posterior bucal que comunica con la arteria bucal. Más tarde, la arteria facial aporta de 1 a 3 ramas a la mitad inferior del músculo buccinador, y continúa más arriba para dar 3 a 5 pequeñas ramas a la mitad anterior del músculo buccinador. La AAPS da pequeñas ramas que penetran en el margen superior del músculo buccinador en su mitad posterior (Fig. 1).

\section{Introduction}

The reconstruction of small defects of the maxillofacial area is normally carried out with local flaps. Large defects are reconstructed with regional vascularized flaps or with microvascularized free flaps. In moderately sized defects there is controversy as to the reconstruction method to be used. On numerous occasions these defects cannot be reconstructed with local flaps due to limitations regarding the type of length of the pedicle, the plastic characteristics of the donor material and the variability of the vascular anatomy. However, the use of microvascular free flaps or regional vascularized flaps may not be indicated due to excessive volume, high morbidity of the donor site, presence of co-morbidity or high surgical risk, and excessive increase in the operating time. In these cases, pedicled flaps can be used such as the temporal, temporoparietal fascia, frontal muscle, nasolabial, palatal, platysma and sternocleidomastoid muscles. Another alternative that has recently become more popular is the buccinator myomucosal flap (BMF).

In 1975 Kaplan 1 used a buccal mucosal flap for the reconstruction of a soft palate. In order to improve vascularization of the mucosa in 1987 Maeda et al ${ }^{2}$ carried out a Kaplan's flap together with buccinator muscle (BM) fibers along its entire length in order to repair a cleft palate. That same year Rayner and Arscott, ${ }^{3}$ described the buccal myomucosal flap pedicled at an angle to the mouth in order to reconstruct a lip. Bozzola et al, 4 in 1989 described the buccal artery (BA) as the principle pedicle for BM. In 1991, Carstens el al, 5 described the myomucosal flap in a BM island flap pedicled to the artery and facial vein $(F A, F V)$. They reported that the main blood supply to the BM did not arrive via the $B A$ rather that it arrived through the FA. Ono et alo in 1997 used a unilateral buccinator myomucosal flap for the reconstruction of complete defects of the vermilion of the lower lip.

In this work we describe in detail the reconstruction of the different defects of the oral cavity using the BMF. A revision of the literature is also carried out, and we report our experience with four cases of oral cavity defects.

\section{Anatomy}

The $B M$ receives its arterial supply from 3 main sources. These are: the BA (internal maxillary artery branch), the $F A$ (external carotid artery branch) and the posterior superior alveolar artery (PSAA) (internal maxillary artery branch). Traditionally the $B A$ was considered to provide the main blood supply to the buccinator muscle. The most recent studies refer to the FA as being the main source of irrigation of the muscle. ${ }^{5}$ The BA goes downwards and forwards under the lateral pterygoid muscle in order to reach the posterior half of the buccinator muscle. The FA provides a posterior buccal branch that links it to the buccal artery. Later, the facial artery provides from 1 to 3 branches to the lower half of the buccinator muscle, and further up it provides 3 to 5 
El drenaje venoso tiene lugar a partir de varias venas que surgen de la cara lateral del MB para formar el plexo venoso bucal (PVB) en la parte posterior del músculo. Este drena a la vena facial (VF) a través de 2 a 4 venas tributarias y también al plexo venoso pterigoideo (PVPt) y a la vena maxilar interna (VMI) a través de la vena bucal (VB), que es comitante de la AB. La VF drena en la vena yugular interna (VYI) a través de la vena facial común (VFC), pero en ocasiones la VF drena directamente en la vena yugular externa (VYE) o en la vena yugular anterior (VYA). ${ }^{7}$

La inervación del MB procede de las ramas temporal y cervical del nervio facial (NF). Ambas convergen cerca de la almohadilla grasa bucal para formar una densa maraña: el plexo bucal (PB). Más de 4 ó 5 ramas alcanzan la parte profunda de la almohadilla grasa bucal y se distribuyen en el MB. Esta amplia inervación permite al cirujano elevar parte del colgajo de MB con pedículo nervioso. El nervio bucal largo (NBL) (la rama sensitiva bucal) penetra por la parte posterior del $\mathrm{MB}$ e inerva profusamente el músculo y la mucosa bucal. El NBL y las ramas bucales del NF se anastomosan para formar el plexo bucal. El NBL puede ser incluido en el colgajo. ${ }^{8}$

\section{Técnica quirúrgica}

El colgajo debe ser tallado $0,5 \mathrm{~cm}$ por debajo del orificio de drenaje del conducto de Stenon ipsilateral al defecto a reconstruir. En este sentido puede ser útil canular el conducto con una sonda. La incisión se realiza a través de la mucosa y el espesor completo del MB hasta el plano graso lateral.

Algunos autores, ${ }^{5}$ propugnan una disección previa de la arteria y vena faciales a través de una incisión nasolabial, que ayudará a definir las ramas al MB. Este abordaje permite esqueletizar de modo adecuado el pedículo vascular facial, y conseguir una longitud de pedículo muy buena. Además permite controlar con mayor seguridad la disección intraoral. Una vez identificados los vasos, se puede realizar la liberación del colgajo muscular o músculomucoso externamente a través de la incisión nasolabial o de una incisión submandibular. Sin embargo, el abordaje más comúnmente utilizado es el intraoral.

Existen diversas aplicaciones reconstructivas con el empleo del $\mathrm{CMB}$. La variante que está pediculada posteriormente lo hace a expensas de la $A B$, la rama bucal posterior de la $A F$ y el PVB. Estos vasos son constantes y no precisan la realización de eco-Doppler preoperatorio. Se realiza la incisión superior, a 5-8 mm inferior a la apertura del conducto de Stenon. Se diseña un colgajo fusiforme desde 1 small branches to the anterior half of the buccinator muscle. The PSAA has small branches that penetrate the upper margin of the buccinator muscle in the posterior half (Fig. 1).

Venous drainage takes place through various small veins that emerge from the lateral side of the BM forming the buccal venous plexus (BVP) in the posterior half of the muscle. This drains into the facial vein (FV) through 2 to 4 tributary veins and also to the pterygoid venous plexus (PtVP) and into the internal maxillary vein (IMV) through the buccal vein (BV) that is concomitant of the $B A$. The FV drains into the internal jugular vein (IJV) through the common facial vein (CFV), but sometimes the FV drains directly into the external jugular vein (EJV) or into the anterior jugular vein (AJV). ${ }^{7}$

The innervation of the $B M$ comes from the cervical and temporal branches of the facial nerve (FN). They both converge near the buccal fat pad forming a dense tangle: the buccal plexus (BP). More than 4 to 5 branches reach the deeper part of the buccal fat pad and they are distributed throughout the BM. This ample innervation allows the surgeon to harvest part of the BM flap with a nerve pedicle. The long buccal nerve ( $L B N)$ (the sensitive buccal branch) penetrates through the posterior part of the BM and it innerves the muscle and buccal mucosa profusely. Anastomosis takes place between the LBN and the buccal branches of the FN forming the buccal plexus. The LBN can be included in the flap. ${ }^{8}$

\section{Surgical technique}

The flap should be harvested $0.5 \mathrm{~cm}$ below the drainage orifice of the Stenon's duct and ipsilateral to the defect to be reconstructed. In this sense, carrying out drainage of the duct can be useful. The incision is made through the mucosa and the complete thickness of the BM to the lateral fat plane.

Some authors, ${ }^{5}$ support previous dissection of the facial arteries and veins through a nasolabial incision that will aid in defining the branches of the BM. This approach allows a suitable skeleton to be provided for the facial vascular pedicle, and a very good pedicle length is achieved. Also it allows a more secure control of the intraoral dissection. Once the veins have been identified, the muscular or musculomucosal flap can be freed externally through a nasolabial inci- 


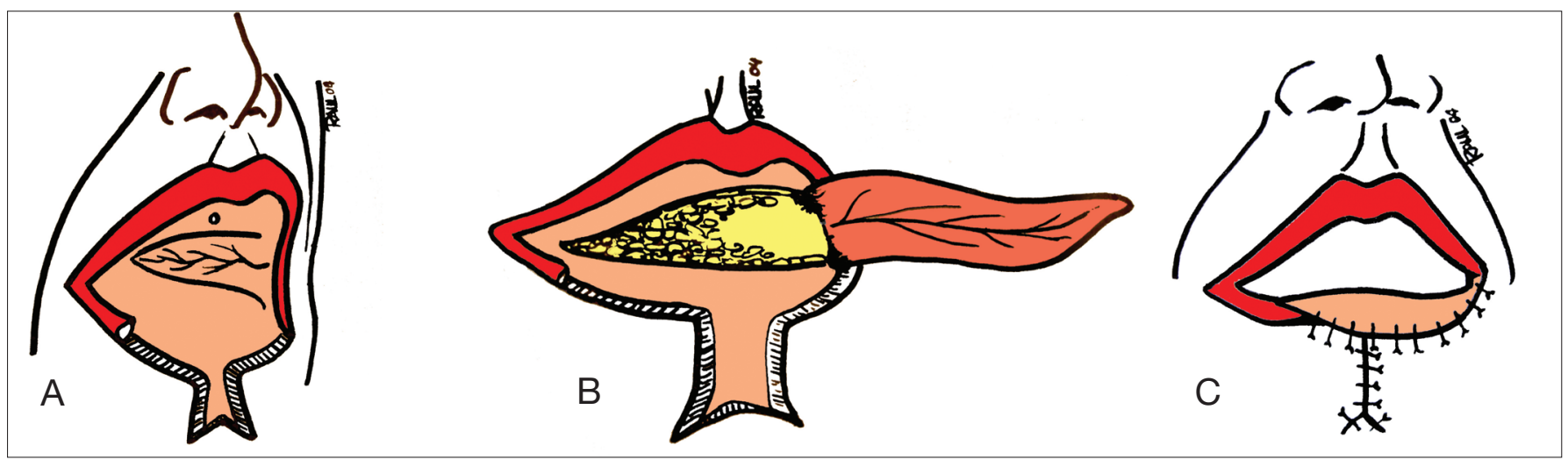

Figura 2. Esquemas del tallado de colgajo miomucoso de buccinador para la reparación de defectos del bermellón inferior. Figure 2. Diagrams of the harvesting of a buccinator myomucosal flap for the repair of defects of the lower vermilion.

$\mathrm{cm}$ anterior al rafe pterigomandibular dirigiéndonos anteriormente hasta la comisura bucal. El margen inferior se diseña a 1-2,5 cm debajo de la primera incisión (dependiendo de si el paciente es niño o adulto). Anteriormente el colgajo puede llegar hasta la comisura o bien tener forma de $\mathrm{Y}$ en el labio superior e inferior. A nivel posterior, la parte muscular del colgajo puede finalizar en el rafe pterigomandibular, mientras que la parte mucosa finaliza $1 \mathrm{~cm}$ por delante de este último. Después de la incisión de la mucosa y el músculo, éste último es elevado medialmente y separado de la fascia bucofaríngea. Se ligan las pequeñas ramas de la AF y se expone la almohadilla grasa bucal. Se continúa la disección en profundidad hasta $1 \mathrm{~cm}$ anterior al rafe pterigomandibular, donde el pedículo vascular posterior hace su entrada y se separa el MB del rafe, teniendo cuidado de no lesionar el paquete vascular. El arco de rotación de este colgajo permite alcanzar el velo palatino, el paladar y la pared faríngea lateral. La reparación de la zona donante se hace mediante cierre directo. ${ }^{7,8}$

La variante pediculada superiormente lo hace a expensas de las ramas bucales anteriores de la AF. Podemos utilizar eco-Doppler para delimitar el curso de las arterias. Se realiza una incisión en el borde inferior a través de mucosa y músculo. Se identifica y liga la AF en su parte más distal, una vez ha dado las ramas referidas. El arco de rotación permite movilizar el colgajo hasta cualquier punto entre la comisura y el canto medial. El colgajo puede alcanzar la órbita a través de un túnel bajo la piel de la región infraorbitaria, para reconstruir la conjuntiva del párpado inferior o la órbita. También puede emplearse en la reconstrucción de defectos del paladar duro, alvéolo, seno maxilar, cavidad nasal y septo, y labio superior e inferior.

La variante pediculada anteriormente a nivel del ángulo bucal puede diseñarse con fibras de MB a lo largo de toda su longitud o solo parcialmente. Se puede diseñar una isla de $1,5 \mathrm{~cm}$ de anchura y $5 \mathrm{~cm}$ de longitud. El colgajo se pedicula sobre la $A F$, que pasa a 1-2 cm inferior al ángulo de la boca. Se ligan la arteria y vena bucal, preferiblemente tras haber visualizado y disecado la AF y VF. La VF pasa a $1-1,5 \mathrm{~cm}$ posterior a la $A F$, en la parte media del MB. Las ramas de la AF: angular, labial superior y labial inferior pueden ligarse. El colgajo con músculo y mucosa se puede trasponer al defecto del bermellón inferior (Fig. 2). Se pueden reparar también defectos de suelo de boca, pero con dimensiones mayores, de $7 \times 5 \mathrm{~cm}$, y colocando un injerto de piel en la zona donante. Si fuera preciso un colgajo de mayor tamaño, se puede trasplantar el con- sion or through a submandibular incision. However, the most common approach used is intraoral.

The BMF can be used in various ways in reconstruction. The variant with a posterior pedicle is done so at the expense of the $B A$, the posterior buccal branch of the FA and of the $B V P$. These veins are constant and a preoperative echo-Doppler is not required. An incision is made above, 5-8 $\mathrm{mm}$ under the aperture of the Stenon's duct. A fusiform flap is designed $1 \mathrm{~cm}$ before the pterygomandibular raphe and taken forwards to the buccal commissure. The lower margin is designed 1-2.5 $\mathrm{cm}$ below the first incision (depending on if the patient is a child or an adult). The front part of the flap can reach the commissure or it can take the form of a $Y$ in the upper and lower lip. At the back, the muscular part of the flap can end in the pterygomandibular raphe while the mucosal part of the flap can end $1 \mathrm{~cm}$ in front of the latter. After the incision into the mucosa and the muscle, the latter is raised medially and separated from the buccopharyngeal fascia. The small branches of the FA are tied and the buccal fat pad is exposed. The dissection is carried on to a depth of $1 \mathrm{~cm}$ in front of the pterygomandibular raphe, where the posterior vascular pedicle enters and the $B M$ is separated from the raphe, taking care not to damage the vascular bundle. The arc of rotation of this flap permits reaching the palatine velum, the palate and the lateral pharyngeal wall. The repair to the donor site is made by means of direct closure. 7,8

The variant with a superior pedicle is done at the expense of the anterior buccal branches of the FA. An echo-Doppler can be used to show the flow of the arteries. An incision is made into the lower border through the mucosa and muscle. The FA is identified and tied at its most distal point after the branches. The arc of rotation allows the flap to be moved to any point between the commissure and the medial canthus. The flap can reach the orbit through the tunnel under the skin in the infraorbital region, in order to reconstruct the lower lid or the orbit. It can also be used to reconstruct the defects of the soft palate, alveolus, maxillary sinus, nasal cavity and septum, upper and lower lip.

The whole of the length of the anteriorly pedicled variant, on a level with the buccal angle, can be designed with 
ducto de Stenon. Generalmente no es preciso seccionar el pedículo del colgajo, pero si fuera necesario puede realizarse con seguridad 3 semanas después de la reconstrucción.

\section{Casos clínicos}

\section{Caso clínico 1}

F.C, mujer de 33 años que acudió a nuestra consulta por presentar fisura palatina no tratada, con paladar posterior competente sin insuficiencia velopalatina, cicatriz labial superior secundaria a intervenciones de labio leporino y maxilar superior hipoplásico. Se realizó cierre de paladar blando con colgajo miofascial de temporal izquierdo y se colocó prótesis de cianocrilato en región temporal. Cuatro años después, la paciente fue intervenida para colocación de injerto de calota fijado en maxilar superior izquierdo y rinoplastia con injerto óseo a nivel de columela. Periódicamente revisada en nuestro Servicio, se objetivó persistencia de fístula oroantral. Dos años después se decide someter a intervención quirúrgica con despegamiento de mucosa palatina adyacente a fístula, tallado de colgajo de mucosa yugal izquierda y músculo buccinador pediculado a la arteria facial izquierda. La evolución fue favorable. No se ha constatado persistencia de la comunicación a los 7 años de la última cirugía.

\section{Caso clínico 2}

M.T, varón de 48 años, fumador de 3 paquetes de cigarrillos/día y bebedor moderado, acudió a nuestra consulta refiriendo lesión a nivel de suelo de boca de 1 año de evolución, y pérdida de $7 \mathrm{~kg}$ de peso. A la exploración se apreció lesión ulcerada a nivel de suelo de boca derecho de $2 \mathrm{~cm}$ de diámetro, que llega hasta línea media. No se palparon adenopatías cervicales. La biopsia diagnóstica fue informada como carcinoma epidermoide infiltrante poco diferenciado. El TC fue informado como masa de partes blandas de $2 \mathrm{~cm}$ de diámetro en posición retrosinfisaria en el suelo de la boca, que cruzaba la línea media hacia el lado izquierdo. El paciente fue intervenido realizándose resección de la lesión, transposición de ambos conductos de Wharton y reconstrucción con colgajo de músculo buccinador del lado derecho pediculado a la arteria facial. La pieza fue informada como carcinoma epidermoide poco diferenciado. El seguimiento a los 6 meses no ha demostrado signos de recidiva locorregional, con viabilidad del colgajo miomucoso de buccinador.

\section{Caso clínico 3}

F.L, paciente mujer de 49 años, ex-fumadora de 1 paquete de cigarrillos/ día, acudió a nuestra consulta por presentar lesión pigmentada en encía vestibular superior y encía palatina de premaxila. Aportaba informe anatomopatológico de biopsia realizada en otro centro con el diagnóstico de melanoma maligno mucoso. A la exploración presentaba una lesión pigmentada a nivel de encía vestibular superior de $0,6 \times 0,5 \times 0,1 \mathrm{~cm}, y$ dos lesiones pigmentadas de encía palatina en premaxila, de 1,5 × 1 y 0,9 0 0,6 cm respectivamente. Asimismo, se observan pequeñas lesiones pigmentadas a nivel de mucosa bucal, labio superior izquierdo, encía inferior izquierda y encía inferior derecha. fibers of $B M$, or only partially. An island can be designed that is $1.5 \mathrm{~cm}$ wide and $5 \mathrm{~cm}$ long. The flap is pedicled onto the $F A$, which passes $1-2 \mathrm{~cm}$ under the angle of the mouth. The artery and buccal vein are tied, preferably after having identified and dissected the FA and FV. The FV passes 1 $1.5 \mathrm{~cm}$ after the FA in the middle part of the BM. The branches of the FA: angular, upper and lower lip can be tied. The flap with muscle and mucosa can be put over the lower vermilion defect (Fig. 2). Defects of the floor of the mouth can be repaired as well, but with larger defects $7 \times 5 \mathrm{~cm}$, and a graft of skin can be placed in the donor area. If a larger sized flap were necessary, the Stenon's duct can be transplanted. Generally, sectioning the pedicle of the flap is not necessary but, if necessary, this can be carried out safely 3 weeks after the reconstruction.

\section{Case reports}

\section{Case report 1}

F.C., a 33 year old female attended our unit with an untreated cleft palate. She had a competent posterior palate with no palatine velum insufficiency, and secondary scarring on her upper lip as a result of hare lip operations and a hypoplastic upper maxilla. The soft palate was closed with a myofascial flap of temporalis muscle from the left side and the cyanocrylate prosthesis was placed in the temporalis area. Four years later, the patient was operated on in order to place a calvarium graft in the upper left maxilla and rhinoplasty was carried out with a bone graft on a level with the columella. She periodically came to our Service for a follow-up, and a persistent oroantral fistula was observed. Two year later, a decision was made to operate in order to release the palatine mucosa adjacent to the fistula, and to harvest a jugal mucosa flap from the left side and to pedicle the buccinator muscle to the left facial artery. The patient progressed favorably. Seven years after the last surgery there has been no sign of any persistent communication.

\section{Case report 2}

M.T., 48 year old male, smoker of 3 packets of cigarettes a day and moderate drinker, attended our unit with a lesion on the floor of the mouth that had been developing for a year. He had lost $7 \mathrm{~kg}$ of weight. On examination an ulcerated lesion could be appreciated on the floor of the mouth on the right side that measured $2 \mathrm{~cm}$ in diameter and reached the midline. No cervical adenopathy was felt. The diagnostic biopsy was of a poorly differentiated infiltrating epidermoid carcinoma. The CT scan revealed a mass of soft tissue with a $2 \mathrm{~cm}$ diameter in a retrosymphysial position on the floor of the mouth that crossed over the midline to the left side. The patient was operated on and the lesion was resected. Both Wharton's ducts were transposed and reconstruction was carried out with buccinator muscle from the right side that was pedicled to the right facial artery. The sample 
Ante nueva biopsia que confirma el diagnóstico de melanoma de mucosa oral, se decide intervención quirúrgica con maxilectomía parcial desde el primer premolar derecho hasta el incisivo central derecho, incluyendo encía insertada, mucosa vestibular y palatina y piezas dentales. En el mismo tiempo quirúrgico se procede a la reconstrucción del defecto con colgajo miomucoso de buccinador pediculado a la arteria facial e injerto óseo de cresta iliaca anterior. La evolución en el postoperatorio fue favorable. El diagnóstico anatomopatológico fue mucosa de encía y hueso subyacente infiltrados por melanoma, con bordes quirúrgicos libres de infiltración tumoral. El seguimiento 6 meses después de la cirugía no ha demostrado signos clínicos o radiológicos (tomografía computerizada (TC)) de recurrencia locorregional ni diseminación a distancia, con viabilidad del colgajo miomucoso de buccinador y del injerto óseo de cresta iliaca anterior (Fig. 3).

\section{Caso Clínico 4}

J.P, varón de 41 años, fumador de 1 paquete/día y bebedor moderado, acudió por presentar una lesión ulcerada en suelo de boca de 3 meses de evolución, que no mejoró con el tratamiento conservador. A la exploración se observó lesión ulcerada con bordes anfractuosos e indurados en suelo de boca anterior derecha, de $10 \mathrm{~mm}$ de longitud. No se palparon adenopatías cervicales. La biopsia es informada como carcinoma epidermoide infiltrante. La RM cervicofacial descartó la existencia de adenopatías cervicales. Se realizó resección de la lesión tumoral en suelo de boca y borde ventrolateral de lengua. Se realizó transposición de ambos conductos de Wharton y reconstrucción con colgajo miomucoso de buccinador del lado derecho. El postoperatorio inmediato cursó sin complicaciones, pero a los tres días se constató una dehiscencia parcial del borde anterior del colgajo. Se decidió actitud conservadora con cierre del defecto por segunda intención. La revisión a los 6 meses mostró viabilidad del colgajo y ausencia de recidiva locorregional (Fig. 4).
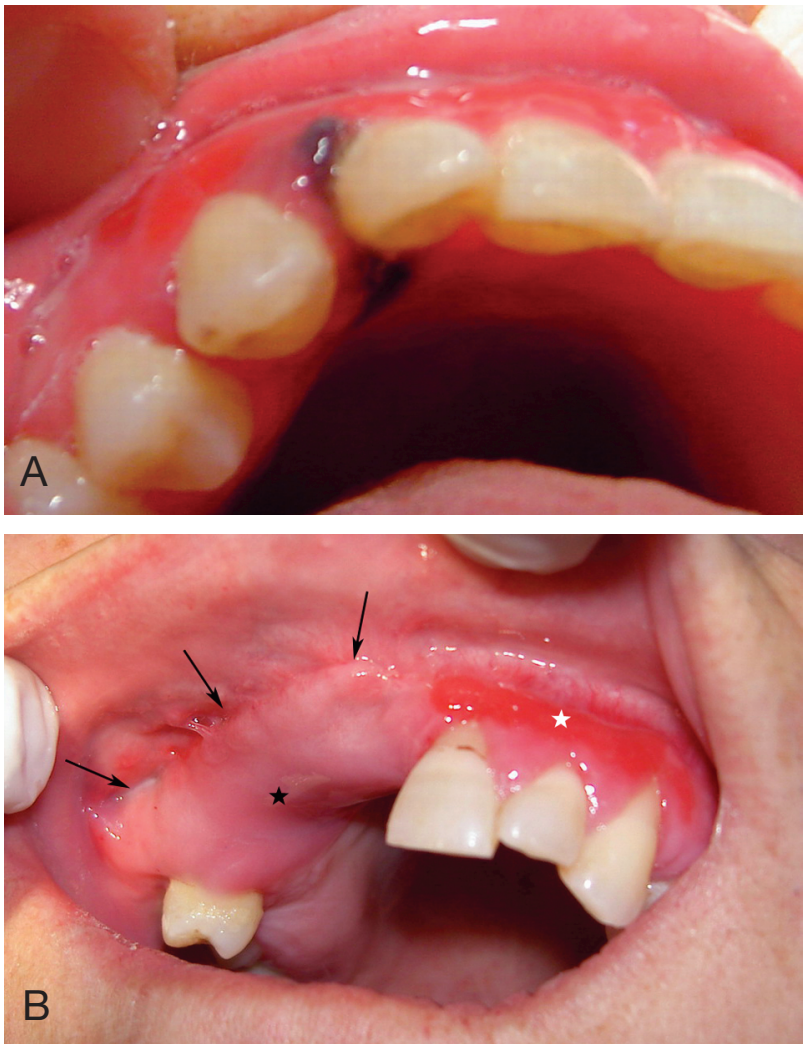

Figura 3. Reconstrucción de defecto en paladar y premaxila tras resección por melanoma de la mucosa oral. Revisión a los 3 meses. Colgajo de buccinador (estrella negra). Borde anterior del colgajo (flechas). Tejido de granulación de cierre por segunda intención tras resección de melanosis de encía (estrella blanca).

Figure 3. Reconstruction of palate and premaxilla defect following resection due to melanoma of the oral mucosa. Follow-up at three months. Buccinator flap (black star). Anterior border of the flap (arrows). Granulation tissue due to second intention closure following resectioning of gingival melanosis (white star).

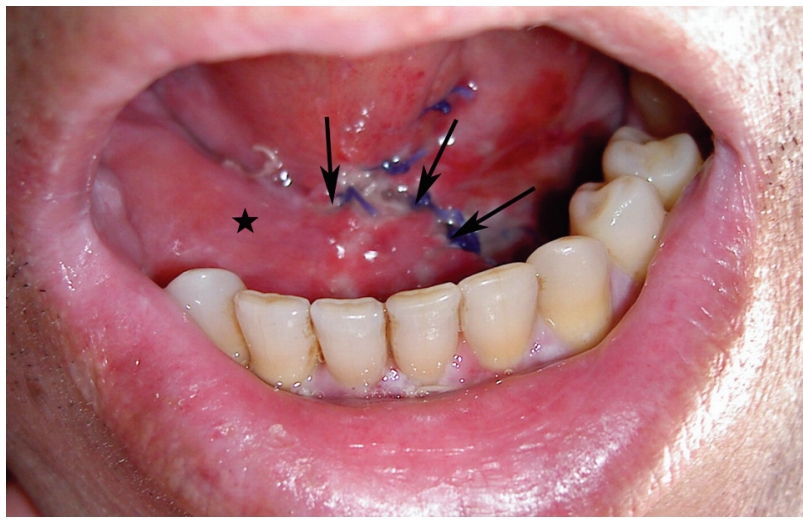

Figura 4. Reconstrucción de defecto de suelo de boca con colgajo de buccinador (estrella negra). Vista postoperatoria inmediata. Borde del colgajo, que supera la línea media (flechas).

Figure 4. Reconstruction of the defect of the floor of the mouth with a buccinator flap (black star). Appearance during the immediate postoperative period. The border of the flap is over the midline (arrows). was reported as being poorly differentiated epidermoid carcinoma. The follow-up at six months did not show any signs of locoregional recurrence, and there was viability of the buccinator myomucosal flap.

\section{Case report 3}

F.L., female patient 49 years old, ex-smoker of 1 packet of cigarettes a day, attended our service due to a pigmented lesion in the upper gingival area and premaxilla portion of the palatal gingiva. She brought an anatopathological report of a biopsy that had been carried out in another center with a diagnosis of malignant mucosal melanoma. On examination she had a pigmented lesion on the upper vestibular gingiva that measured $0.6 \times 0.5 \times 0.1 \mathrm{~cm}$ and two pigmented lesions of the palatal gingiva in the premaxilla area that measured $1.5 \times 1$ and $0.9 \times 0.6$ $\mathrm{cm}$ respectively. Other pigmented lesions were also observed in the buccal mucosa area, upper left lip, lower left gingiva and lower right gingiva.

With a new biopsy that confirmed the diagnosis of melanoma of oral mucosa, a decision was made to operate and to perform a partial maxillectomy from the first premolar on the right to the right central incisor, including part of the inserted incisor, vestibular and palatine mucosa and teeth. In the operating time the defect was then reconstructed with a myomucosal flap of buccinator muscle pedicled to the facial artery and bone graft of anterior iliac crest. There was good progress postoperatively. The 


\section{Discusión}

El colgajo miomucoso de buccinador es una buena alternativa para la reconstrucción de defectos de tamaño moderado en el área maxilofacial. Proporciona mucosa intacta, puede estar o no estar inervado, aporta suficiente masa muscular y tiene un arco de rotación amplio, con lo cual cubre la mayoría de los defectos ipsilaterales de paladar y maxilares, cruzando incluso la línea media. ${ }^{9}$ También es útil en la reconstrucción del labio inferior, lengua, suelo de boca, ${ }^{10}$ defectos de tercio medio facial y periorbitarios. Además, la anatomía vascular es predecible. Se consigue el cierre de la zona donante de modo directo o mediante el empleo de injertos de piel o aloinjertos. En la serie presentada se utilizó para la reparación de defectos post-resección oncológica en el suelo de la boca (2) y paladar (1) (Fig. 5) y para la reparación de fisura palatina (1).

En los casos en los que existen defectos de más de $1 / 3$ del bermellón labial inferior puede ser muy útil el empleo de este colgajo. ${ }^{6}$ Debido a la inclusión de fibras musculares, el bermellón neoformado tiene características muy parecidas a las originales. Si el colgajo es fino puede recuperarse la sensibilidad a partir del injerto de labio inferior. Como desventajas, se refiere la diferencia de color con respecto al del bermellón residual, que el colgajo tiende a la sequedad durante un periodo de tiempo variable, con desarrollo de cambios queratósicos, y que el ángulo comisural se redondea cuando se usan colgajos para la práctica totalidad del bermellón. En estos casos es necesario un segundo tiempo quirúrgico para realizar una Zplastia. ${ }^{11}$ De igual modo, puede ser una buena alternativa para la reconstrucción de la hemi-lengua, 7 con menor morbilidad de la zona donante que el injerto libre antebraquial, y con características histológicas similares a la lengua. Además, proporciona reinervación de la lengua y no deja una zona donante visible. En cualquier caso, si el defecto es mayor, puede emplearse injerto libre antebraquial o CMB bilateral.

Stofman y cols., ${ }^{10}$ en una serie de 31 casos, refieren la dehiscencia de la sutura en dos casos de reconstrucción de defectos en paladar. Creemos que esta complicación puede evitarse mediante el empleo
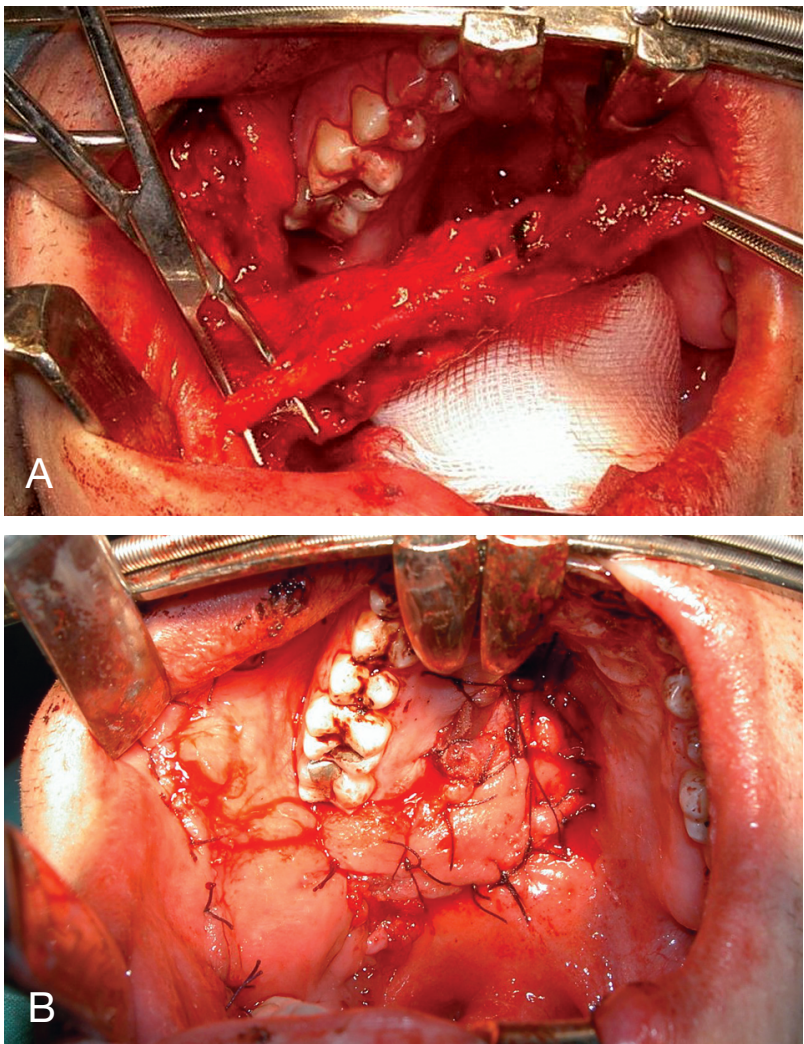

Figura 5. Tallado del colgajo miomucoso de buccinador pediculado a la arteria buccal. Reparación de defecto de paladar mediante la colocación de colgajo miomucoso de buccinador pediculado a la arteria bucal.

Figure 5. Harvesting of the buccinator myomucosal flap, which is pedicled to the buccal artery. Repair of the palatal defect by placing a buccinator myomucosal flap that is pedicled to the buccal artery.

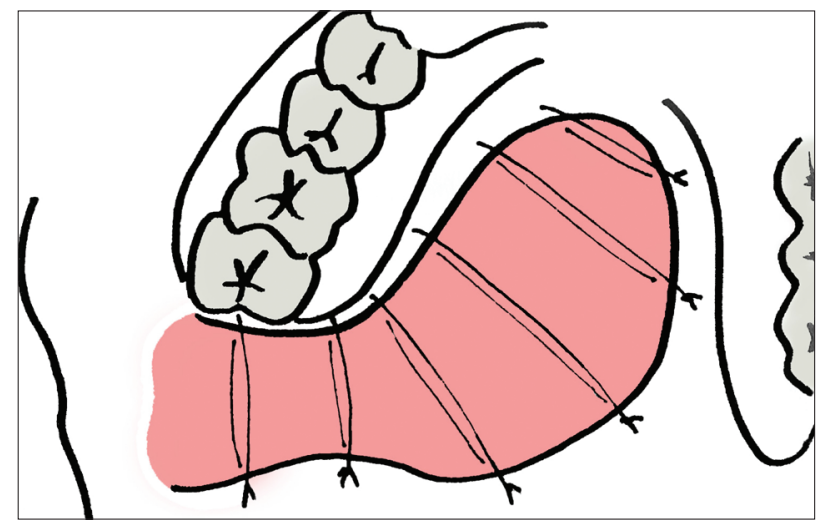

Figura 6. Técnica de «sutura en abrazadera» para reconstrucción de defectos del paladar por medio de colgajo miomucoso de buccinador.

Figure 6. Loop suture technique for the reconstruction of palatal defects using the buccinator myomucosal flap. anatomopathologic diagnosis was of gingival mucosa and underlying bone infiltrated by melanoma, with surgical margins that were free of tumor infiltration. The follow-up 6 months after surgery did not show clinical or radiological signs (computed tomography (CAT)) of locoregional recurrence or distant dissemination, and there was viability of the buccinator myomucosal flap and of the bone graft of anterior iliac crest (Fig. 3).

\section{Case report 4}

J.P., 41 year old male, smoker of one packet a day and moderate drinker, attended our service due to an ulcerated lesion on the floor of his mouth, that did not improve with conservative treatment. On examination an ulcerated lesion was observed with rough, hard borders and in the anterior portion of the floor of the mouth on the right side with a length of 10 $\mathrm{mm}$. Cervical adenopathy was not felt. The biopsy reported infiltrating epidermoid carcinoma. Cervical adenopathy was ruled out through cervicofacial MR. The tumor lesion on the floor of the mouth and ventrolateral border of the tongue was resectioned. Both Wharton's ducts were transposed and a buccinator myomucosal flap was used to reconstruct the right side. There were no complications during the immediate postoperative period, but three days later there was partial dehiscence of the anterior border of the flap. A conservative approach was decided on with second intention closure of the defect. The follow-up six months later showed flap viability and an absence of locoregional recurrence (Fig. 4). 
de una técnica de sutura consistente en varias dobles lazadas dispuestas de modo paralelo, con un brazo largo cruzando sobre el colgajo desde la encía proximal a la encía distal y un brazo corto sobre el colgajo sin atravesar las incisiones. Este apoyo de las suturas sobre el colgajo disminuye la probabilidad de acumulación de hematoma o seroma entre el colgajo y la concavidad del paladar óseo (Fig. 6). ${ }^{12}$ No se han descrito otras complicaciones relevantes, salvo hipoestesia residual en la parte lateral de la comisura bucal del lado del colgajo. ${ }^{10}$ El daño al ramo marginal del nervio facial es posible pero improbable, aunque se favorece si la disección se inicia en el borde mandibular inferior. ${ }^{7}$

Sin embargo, y a pesar de la relativa seguridad de este colgajo, existen ciertas limitaciones. Para la reconstrucción de defectos a nivel de la cresta alveolar, por ejemplo, los colgajos de encía son los primeros que han de tenerse en cuenta en la medida de lo posible, debido a las diferencias existentes en el tipo de mucosa. En ocasiones, la colocación de la mucosa yugal hacia la cavidad oral no es posible en las reconstrucciones de defectos de paladar, y el colgajo ha de rotarse $360^{\circ}$, con la mucosa dirigida hacia la cavidad nasal. En estos casos se puede emplear un injerto de piel o membrana de Gore-tex ${ }^{\circledR}$ para la cobertura de la cara oral del colgajo. ${ }^{9}$ Es preciso considerar la limitación en relación a la cantidad de tejido aportado. Además, la morbilidad de la zona donante en defectos grandes puede ser importante. En los casos en los que se talla un CMB de gran tamaño, se hace precisa la reparación con injertos de piel, pues el cierre por segunda intención puede ocasionar gran retracción cicatricial, con limitación para la apertura oral. En ninguno de los casos de nuestra serie fue necesario el empleo de injertos para el cierre de la zona donante, siendo suficiente el cierre primario de la mucosa oral. En aquellos casos en los que se objetiva la invasión tumoral de la vena y arteria faciales, no debe transferirse el CMB. En la experiencia de los autores, el CMB pediculado a las RBP puede crear problemas en relación a la mordedura del pedículo en el postoperatorio inmediato y precoz. La exodoncia de terceros molares superiores puede ser de gran ayuda para facilitar el paso del pedículo desde la región yugal al defecto a reconstruir. Carstens y cols. ${ }^{5}$ refieren la realización de una ostectomía del proceso alveolar, para favorecer el paso atraumático del pedículo vascular del CMB. En cualquier caso, si existe obstrucción mecánica y mordida del colgajo, se puede realizar la sección del pedículo en un segundo tiempo quirúrgico, transcurridas 3-4 semanas.

Mediante esta técnica se ha descrito la reconstrucción de numerosos defectos correspondientes a fístulas oroantrales, nasopalatinas, y orocutáneas; cobertura de injertos óseos maxilares; defectos labiales, de lengua y de suelo de boca; exposiciones de mandíbula por osteorradionecrosis y exposiciones de placas de fijación; defectos periorbitarios y de tercio medio facial; defectos de cavidad nasal y septum; defectos de paladar duro, paladar blando y pared faríngea; y cierre velofaríngeo insuficiente. ${ }^{1-3,6,7,10,13-17}$ El rico aporte vascular permite diseñar las diversas variantes que mejor se adapten al defecto, con buen relleno y con la posibilidad de aportar inervación. A pesar de la rica vascularización del CMB, y a la defendida por Zhao y cols. ${ }^{8}$ multiplicidad de aporte vascular, que permitiría la supervivencia del colgajo independientemente de su diseño, creemos que una adecuada y cuidadosa disección del mismo, y la localización de uno de sus dos pedículos principales, la AF o las RBP, incrementan la tasa de supervivencia del mismo.

\section{Discussion}

The buccinator myomucosal flap is a good alternative for the reconstruction of moderate sized defects in the maxillofacial area. It provides a mucosa that is intact, it can be innervated or not, it has sufficient muscular mass and a wide arc of rotation, which enables covering most of the ipsilateral defects of the palate and maxilla, even crossing over the midline. ${ }^{9}$ It is also useful for the reconstruction of the lower lip, tongue, floor of the mouth, 10 midface and preorbital defects. Its vascular anatomy is also predictable. Closure of the donor area is achieved directly or by means of skin grafts or allografts. In the series presented it was used to repair oncological defects postresection of the floor of the mouth ${ }^{2}$ and palate1 (Fig. 6) and for the repair of a cleft palate.1

In cases where there are defects affecting more that a third of the lower lip vermilion the use of this flap can be very useful. ${ }^{6}$ Given that muscle fiber is included, the newly formed vermilion has characteristics that are very similar to the original. If the flap is fine, sensitivity is regained from the lower lip graft. The disadvantages are that there is a difference in color with regard to the residual vermilion, the flap tends to be dry during a variable period of time, keratosic changes can take place, and the angle of the commissure is rounded when flaps are used for practically all the vermilion. In these cases a second operation is needed for carrying out Zplasty. ${ }^{11}$ It can also be a good alternative for the reconstruction of the hemi-tongue 7 as there is less morbidity in the donor area than with the forearm free flap and it has similar characteristics to the tongue. In addition it provides reinnervation to the tongue and there is no visible donor area left. In any event, if the defect is large, a forearm free flap can be used or a bilateral BMF.

Stofman et al10 in a series of 31 cases reported dehiscence of the suture in two cases of reconstruction of palate defects. We believe this complication can be avoided by using a suture technique consisting in various double loops parallel to each other, with a long arm crossing over the flap from the proximal gingiva to the distal gingiva, and a short arm going over the flap but not through the incisions. This suture support over the flap reduces the probabilities of an accumulation of hematoma or seroma between the flap and the concavity of the palatal bone (Fig. 6).12 No other relevant complications have been described, except for residual hypoesthesia in the lateral part of the buccal commissure on flap side. ${ }^{10}$ Damage to the marginal branch of the facial nerve is possible but improbable, although if the dissection is started at the lower mandibular border this is more likely.

In spite of this flap being relatively reliable, there are however certain limitations. For the reconstruction of defects in the alveolar crest area for example, gingival flaps should first be considered when possible, due to the differences in the type of mucosa. On occasions, placing the jugal mucosa facing the oral cavity is not possible in reconstruction of the palate, and the flap has to be rotated $360^{\circ}$, with the mucosa 


\section{Conclusiones}

En conclusión, se trata de una técnica predecible, relativamente sencilla y con gran versatilidad. Recientemente, empleamos esta técnica en cuatro casos con defectos postablativos de tamaño moderado en la cavidad oral. Abogamos por la utilización de este colgajo para defectos intraorales de tamaño moderado, debido a la relativa sencillez de la técnica utilizada, al abundante aporte vascular del MB, que favorece la viabilidad del mismo, y a la escasa morbilidad de la zona donante. Obtuvimos resultados óptimos en todos los casos, con mínima o nula morbilidad de la zona donante. Se hacen precisas series mayores para comparar los resultados con otras técnicas de reconstrucción mediante colgajos pediculados o injertos libres vascularizados.

\section{Bibliografía}

1. Kaplan EN. Soft palate repair by levator muscle reconstruction and a buccal mucosal flan. Plast Reconstr Surg 1975;56:129.

2. Maeda K, Ojimi H, Utsugi R, Ando SA. T-shaped musculomucosal flap method for cleft palate surgery. Plast Reconstr Surg 1987;79:888.

3. Rayner CR, Arscott GD. A new method of resurfacing the lip. Br J Plast Surg 1987;40:454.

4. Bozzola AR, Gasques JA, Carriquiry CE, Cardoso de Oliveira M. The buccinator musculomucosal flap: anatomic study and clinical application. Plast Reconstr Surg 1989;84:250.

5. Carstens MH, Stofman GM, Hurwitz DJ, Futrell JW, Patterson GT, Sotereanos GC. The buccinator myomucosal island pedicle flap: anatomic study and case report. Plast Reconstr Surg 1991;88:39.

6. Ono I, Gunji H, Tateshita T, Sanbe N. Reconstruction of defects of the entire vermillion with a buccal musculomucosal flap following resection of malignant tumors of the lower lip. Plast Reconstr Surg 1997;100:422.

7. Zhao Z, Zhang Z, Li Y, y cols. The buccinator musculomucosal island flap for partial tongue reconstruction. J Am Coll Surg 2003;196:753-60.

8. Zhao Z, Li S, Yan Y, y cols. New buccinator myomucosal island flap: anatomic study and clinical application. Plast Reconstr Surg 1999;104:55-64.

9. Anastassov GE, Schwartz S, Rodríguez E. Buccinator myomucosal island flan for postablative maxillofacial reconstructions: a report of 4 cases. J Oral Maxillofac Surg 2002;60:816-21.

10. Stofman GM, Carstens MH, Berman PD, Arena S, Sotereanos GC. Reconstruction of the floor of the mouth by means of an anteriorly based buccinator myomucosal island flap. Laryngoscope 1995;105:90-6.

11. Ono I, Ariga T, Gunji $\mathrm{H}, \mathrm{y}$ cols. A method of three triangular flaps as a secondary postoperative prodedure after reconstruction of the lower lip by Estlander's method. Plast Reconstr Surg 1992;90:700.

12. González-García R, Naval-Gías L, Rodríguez-Campo FJ. Simple suture technique of securing buccinator myomucosal flaps for the reconstruction of large palatal defects. Plast Reconstr Surg (en prensa).

13. Caubet Biayna J, Iriarte Ortabe JI, Lasa Menéndez V, Pueyo J. Buccinator flap for closure of large palatal defects. Oral Surg Oral Med Oral Pathol Oral Radiol Endod 1996;81:507-8.

14. Caubet Biayna J, Iriarte Ortabe JI, Pueyo J. Reconstruction of a palatal defect with pedicled myomucosal flap of buccinator muscle. An Otorrinolaringol Ibero Am 1998;25:263-70.

15. Licameli GR, Dolan R. Buccinator musculomucosal flap: applications in intraoral reconstruction. Arch Otolaryngol Head Neck Surg 1998;124:69-72.

16. Hill C, Hayden C, Riaz M, Leonard AG. Buccinator sandwich pushback: a new technique for treatment of secondary velopharyngeal incompetence. Cleft Palate Craniofac / 2004;41:230-7.

17. Kuran I, Sadikoglu B, Turan T, Hacikerin S, Bas L. The sandwich technique for closure of a palatal fistula. Ann Plast Surg 2000;45:434-7. facing the nasal cavity. In these cases a graft of Gore-tex, skin or membrane can be used for covering the oral side of the flap. ${ }^{9}$ Considering the limitations with regard to the quantity of tissue provided is necessary. Donor site morbidity when the defects are large can, in addition, be considerable. In those cases where a BMF is harvested that is very large, skin grafts are needed for reparation, as second intention closure can lead to considerable scar retraction and oral aperture limitation. In none of the cases in our series was the use of grafts necessary for closing the donor area, with primary closure of the oral mucosa being sufficient. In those cases where tumor invasion of the veins and arteries is observed, the BMF should not be transferred. In the experience of the authors, the BMF pedicled to the PBB can create problems with regard to pedicle biting during the immediate and early postoperative period. The removal of upper third molars can be of great help for passing the pedicle from the jugal area to the defect to be reconstructed. Carsten et als reported carrying out an osteotomy of the alveolar process in order to facilitate the atraumatic transfer of the vascular pedicle to the $B M F$. If there is any mechanical obstruction and biting of the flap, the pedicle can in any event be sectioned in a second operation 3-4 weeks later.

By using this technique the reconstruction of numerous defects corresponding to oroantral, nasopalatine and orocutaneous defects have been described; maxillary bone graft cover; lip, tongue and floor of the mouth defects; exposure of the mandible as a result of osteoradionecrosis and exposure of fixture plates; periorbital defects of the midface; defects of the nasal cavity and septum; defects of the hard palate, soft palate and pharyngeal wall; and insufficient velopharyngeal closure ${ }^{1-3,6,7,10,13-17}$. The rich vascular supply allows designing the various variants that are best suited to the defect, with a good filling and with the possibility of providing innervation. In spite of the rich vascular supply of the $B M F$, and defended by Zhao et als for its multiple vascular supply that would enable the flap to survive regardless of its design, we believe that a suitable and careful dissection, and the location of one of its two main pedicles, the FA or the $P B B$, would increase survival rates.

\section{Conclusions}

To conclude, this is a predictable, relatively simple technique that has great versatility. Recently, we used this technique in four cases of postablative defects of a moderate size in the oral cavity. We support the use of this flap for intraoral defects of a moderate size due to the simple technique involved, the abundant vascular supply of the BM favoring the viability of the flap, and the limited donor site morbidity. We obtained optimal results in all cases, with minimum or no morbidity at the donor site. Larger series are needed in order to compare the results with other reconstruction techniques using pedicled flaps or free-vascularized flaps. 